\title{
Hepatitis $C$ virus genotypes circulating in district Swat of Khyber Pakhtoonkhaw, Pakistan
}

\author{
Inamullah', Muhammad Idrees ${ }^{2,4^{*}}$, Habib Ahmed ${ }^{1}$, Sajid-ul-Ghafoor ${ }^{1}$, Muhammad Ali ${ }^{2}$, Liaqat Ali ${ }^{2}$, Aziz Ahmed ${ }^{3}$
}

\begin{abstract}
Hepatitis C virus (HCV) is the leading cause of chronic hepatitis worldwide and its subtypes/genotypes are clinically important for clinical management and vaccine development. The present study describes frequency distribution of different HCV genotypes and their treatment status in HCV RNA positive patients from district Swat. A total of $185 \mathrm{HCV}$ infected sera were analyzed by molecular genotyping assay. The most prevalent genotype was 3a (34.1\%), followed by $2 \mathrm{a}(8.1 \%), 3 \mathrm{~b}(7 \%)$ and $1 \mathrm{a}(5.4 \%)$. The samples found untypable by the present method of genotypes was $37.8 \%$ while, patients with mixed genotype infections were $7.6 \%$. More than $80 \%$ of untypable cases were from those HCV patients who had received interferon plus ribavirin standard therapy in the past and either were non-responders and were relapsed thereafter or were under treatment. In conclusion, genotype $3 \mathrm{a}$ is the most prevalent HCV genotype in the region. A high prevalence rate of untypable genotypes is present in treated patients that need further investigation for the successful genotyping by developing new assays or using viral sequencing method.
\end{abstract}

\section{Background}

Hepatitis C virus (HCV) is a positive single strand RNA virus of Flaviviridae family $[1,2]$ that is approximately $9.6 \mathrm{~Kb}$ in length having a $5^{\prime}$ non-coding region $\left(5^{\prime} \mathrm{NCR}\right)$, a long open reading frame (ORF) encoding a polyprotein precursor of 3,000 amino acids and 3'NCR. Functions of $5^{\prime} \mathrm{NCR}$ as an internal ribosomal entry site (IRES) is important for cap-independent translation of the viral RNA [3]. The virus infect hepatocytes and B lymphocytes of human cells $[4,5]$, and produce 10 trillion virus particles per day, even in the late phase of infection [1]. Viral infection is the major cause of liver cirrhosis in approximately $20 \%$ of patients that after 10 years lead to hepatocellular carcinoma (HCC) in a subset of incidence of 3\%per year [6]. The infection is also associated with cryoglobulinaemia [7] non-Hodgkin's lymphoma [8] and glomerulonephritis [9]. There are 200 million people of the world population are infected with HCV [10] of which the seroprevalence rate is about $1 \%$ in North America, Mediterranean and in Asian countries it is about 3-4\%, while in central Africa and Egypt it is $10-20 \%[11,12]$.

\footnotetext{
* Correspondence: idrees.khan96@yahoo.com

${ }^{2}$ National Centre of Excellence in Molecular Biology, University of the Punjab, Lahore, Pakistan

Full list of author information is available at the end of the article
}

Globally six major Hepatitis C virus (HCV) genotypes and multiple subtypes have been identified and are generally studied for epidemiology, vaccine development and clinical management of the infection [13]. Interferon in combination with ribavirin is the only available approved treatment for chronic hepatitis C [14]. In Western patients the initial responses have been reported to be between $40-70 \%$ but sustained response was noted in only $10-25 \%$ after treatment [15]. Evidence shows that HCV genotype 2 and 3 infected patients are more likely to have a sustained virological response to anti-viral treatment than genotype- 1 infected patients [16]. Combine treatment with interferon and ribavirin have $65 \%$ and $30 \%$ sustained virological response to HCV genotype 2, 3 and 1 respectively $[17,18]$.

The worldwide distribution and relative prevalence of these three HCV genotypes varies from one geographic region to another. In the United State of America and Europe the most common subtypes are $1 \mathrm{a}$ and $1 \mathrm{~b}$ [19-21], While subtype $1 b$ is most commonly found in Japan [22]. HCV Subtype 2a and $2 \mathrm{~b}$ are mostly found in North America, Europe, and Japan while 2c is found only in northern Italy [16,20-22]. In North Africa and the Middle East the most common genotype is 4 while genotype 5 and 6 are found in South Africa and Hong Kong, respectively [23,24]. Genotypes 7, 8, and 9 have 
been reported only in Vietnamese [25] and genotypes 10 and 11 are commonly found in Indonesian patients [26]. It has been proposed that genotypes 7 through 11 should be consider as variants of the same group and classified as a single genotype, type $6[27,28]$.

On the distribution of hepatitis $\mathrm{C}$ virus genotypes, only a few numbers of studies are available from Punjab and Sindh provinces of Pakistan [29-31]. The frequency distribution of various HCV genotypes in Khyber Pakhtoonkhaw (KPK) are recently reported in one study [13] in which HCV genotypes $1 \mathrm{a}, 1 \mathrm{~b}, 3 \mathrm{a}$ and $3 \mathrm{~b}$ are commonly found in various parts of KPK among these genotypes 3a is frequently available [13]. Study on the molecular genotyping of $\mathrm{HCV}$ prevalent in KPK is limited. Therefore, this study was conducted to find out the molecular epidemiology of various HCV genotypes and subtypes present in Swat district of KPK.

\section{Methods}

\section{Subjects}

A total of 185 patients infected with Hepatitis $C$ virus were selected for HCV Genotyping. Informed consent was taken from each infected patient, containing age, sex, demographic characteristic, apparent mode of disease transmission, area/district, and estimated time of infection along with complete address and contact numbers of the patients. Blood samples were collected from patients by visiting hospitals in different area of swat.

\section{Qualitative PCRs for HCV RNA}

Reverse transcriptase (RT) PCR described by idress et al [30] was done for the detection of HCV RNA. RNA was isolated from $100 \mu \mathrm{l}$ patient's sera using Quigen RNA extraction kit according to the kit protocol. Nested PCR were performed using Taq DNA polymerase enzyme (Fermentas Technologies USA) in a volume of $20 \mu \mathrm{l}$ reaction mix. The nested PCR products were visualized on $2 \%$ agarose gel.

\section{Genotyping of HCV}

Type-specific HCV genotyping procedure as described previously in detail [31] was used. About $10 \mu \mathrm{l}$ of $\mathrm{HCV}$ RNA was reverse transcribed to cDNA using $100 \mathrm{U}$ of M-MLV RTEs at temperature of $37^{\circ} \mathrm{C}$ for 50 minutes. Two $\mu \mathrm{l}$ synthesized cDNA was used for PCR amplification of 470-bp region from $\mathrm{HCV} 5$ 'NCR along with core region by first round PCR amplification. The amplified first round PCR product were subjected to two second rounds nested PCR amplifications. One with mix-I primers set and the second with mix-II primers set in a reaction volume of $10 \mu \mathrm{lmix}-\mathrm{I}$ had specific genotype primers set for $1 \mathrm{a}, 1 \mathrm{~b}, 1 \mathrm{c}, 3 \mathrm{a}, 3 \mathrm{c}$ and 4 genotypes and mix-II contain specific genotype primers set for $2 \mathrm{a}, 2 \mathrm{c}$, $3 \mathrm{~b}, 5 \mathrm{a}$, and $6 \mathrm{a}$ genotypes.
After second round of PCR, the products were separated by $2 \%$ agarose gel and ethidium bromide was used for staining to visualize the gel under UV transilluminator. A DNA ladder of 100-bp (Invitrogen, Corp., California, USA) was run in each gel as DNA size marker and the HCV genotype for each sample was confirmed by HCV genotype-specific PCR band. Gel documentation system (Geldoc System, Eppendorf Inc, Germany) was used for gel photograph. The sensitivity of the assay is about $250 \mathrm{IU}$ per $\mathrm{ml}$ sample and specificity is $97 \%$.

\section{Statistical analysis}

Data was analyzed and summarize by using statistic software SPSS version 16.0 for windows. ANOVA and t-test was applied to assess the statistical significance of the data. The data was obtainable as mean values or number of patients. P-value less than 0.05 was considered as significant.

\section{Results}

Total of $185 \mathrm{HCV}$ positive samples from district Swat were selected for $\mathrm{HCV}$ genotype analysis. Among them $105(56.8 \%)$ were males and $80(43.2 \%)$ were females with 171 (92.4\%) married and only 14 (7.6\%) unmarried patients. Mean age of the patients was 34.72 years. Most of the patients had no previous history of drug addiction, only $17(9.2 \%)$ and 25 (13.5\%) of the patients were smokers and snuff users respectively while, no patient was observed with injection drug use.

Table 1 shows age wise distribution of different genotypes prevalent in District Swat. Total no of patients successfully genotyped were 115 (62.16\%). Total number of HCV 3a genotype samples were 63 (34.1\%), 2a (8.1\%), $3 \mathrm{~b}(7 \%)$ and $1 \mathrm{a}(5.4 \%)$. Mixed infections of two different genotypes were observed in $14(7.6 \%)$ while $70(37.8 \%)$ of the patients were untypable by the mentioned method. This shows that most prevalent genotype is $3 \mathrm{a}$ followed by 2a, 3b and 1a. High HCV infection rate of $42.7 \%$ was observed in the age group of 20 to 30 years while only $0.5 \%$ of the patients were of the age above 60 years. The HCV infection was found more prevalent

Table 1 Age wise distribution of the patients genotyped

\begin{tabular}{clllllll}
\hline Age in years & \multicolumn{8}{c}{ Genotype } \\
\cline { 2 - 8 } & 3a & 2a & 1a & 3b & Untypable & Mixed & Total \\
\hline $10-20$ & 1 & 1 & 0 & 0 & 4 & 0 & $6(3.24 \%)$ \\
\hline $20-30$ & 27 & 5 & 5 & 8 & 26 & 8 & $79(42.7 \%)$ \\
\hline $30-40$ & 18 & 3 & 2 & 2 & 20 & 3 & $45(24.32 \%)$ \\
\hline $40-50$ & 13 & 4 & 2 & 3 & 17 & 2 & $41(22.16 \%)$ \\
\hline $50-60$ & 3 & 2 & 0 & 0 & 1 & 1 & $7(3.78 \%)$ \\
\hline$>60$ & 1 & 0 & 1 & 0 & 2 & 0 & $4(2.16 \%)$ \\
\hline Total & 63 & 15 & 10 & 13 & 70 & 14 & 185 \\
\hline
\end{tabular}


in married patients (92.4\%) as compared to non-married persons.

Table 2shows successfully genotyped and non-genotyped samples based on anti-viral treatment status of the patients. Of the total 70 untypable cases, 58 (47.9\%) were from those patients who had received or were receiving interferon plus ribavirin standard therapy in the past and either were non-responders or were relapsed thereafter and only 1 (9.1\%) was from untreated group. Those patients who were unaware about their treatment status in the past, 11 out of $53(20.8 \%)$ were found with untypable genotypes.

Different mode of contamination of various $\mathrm{HCV}$ genotypes is clear from table 3 . In $26.48 \%$ of the $\mathrm{HCV}$ infected population the mode of contamination was surgeries, in $12.4 \%$ was blood transfusion, $10.8 \%$ (pregnant females) got infection during deliveries and $10.3 \%$ had visited foreign countries especially Afghanistan in past and probably got infected over there. The mode of contamination was unknown in $40.0 \%$ of the infected individuals.

Results of the multivariate ANOVA showed that the genotype prevalence is independent of age of the patient $(\mathrm{p}=0.879)$, gender $(\mathrm{p}=0.214)$ and marital status $(\mathrm{p}=$ $0.291)$ at $95 \%$ confidence interval $(\alpha=0.05)$. Similarly, treatment status of the patients were also shown to be independent of age, gender and marital status $(\mathrm{p}>0.05)$ at $95 \%$ CI. Analysis of paired sample t-test showed that all the six different genotypes are independent of age of the patients ( $\mathrm{p}>0.05)$ at CI of $95 \%$.

\section{Discussion}

Swat is a district with a population of 12'57'602 (according to 1998 censuses) located in the Khyber Pakhtoonkhaw (KPK) province of Pakistan [32]. Hepatitis C virus seropositivity in Swati population was reported to be $13.8 \%$ while HCV RNA positivity was $4.7 \%$ [33]. In this study, $185 \mathrm{HCV}$ RNA positive samples were analyzed for genotyping. The most prevalent genotype was $3 \mathrm{a}$ (34.1\%), followed by $2 \mathrm{a}(8.1 \%), 3 \mathrm{~b}(7 \%), 1 \mathrm{a}(5.4 \%)$ while, mixed genotype infection were $7.6 \%$. The rate of untypable genotype was $37.8 \%$ in the current study. Recently Ahmad et al. [33] investigated the prevalence of different genotypes in district Swat and found $49.5 \%$ prevalence of $3 \mathrm{a}$ genotype, $3 \mathrm{~b}$ (3.2\%), mixed genotypes infection (8.7\%) and untypable (3.6\%) [13]. Ali et al. [33] genotyped $415 \mathrm{HCV}$ positive patients from KPK
Table 3 Status of the patient Infectious Detection * Genotype Cross tabulation

\begin{tabular}{|c|c|c|c|c|c|c|c|}
\hline \multirow[t]{2}{*}{ Infectious Detection } & \multicolumn{6}{|c|}{ Genotype } & \multirow[t]{2}{*}{ Total } \\
\hline & $3 a$ & Untypable & $2 a$ & Mixed & $1 a$ & $3 b$ & \\
\hline $\begin{array}{l}\text { HCV positive (Surgical } \\
\text { Patients) }\end{array}$ & 15 & 20 & 6 & 3 & 2 & 3 & $\begin{array}{r}49 \\
(26.48 \%)\end{array}$ \\
\hline $\begin{array}{c}\text { HCV positive (Pregnant } \\
\text { women) }\end{array}$ & 7 & 10 & 2 & 0 & 1 & 0 & $\begin{array}{r}20 \\
(10.8 \%)\end{array}$ \\
\hline $\begin{array}{l}\text { HCV positive (Blood } \\
\text { Donors) }\end{array}$ & 9 & 7 & 1 & 3 & 3 & 0 & $\begin{array}{r}23 \\
(12.4 \%)\end{array}$ \\
\hline Unknown & 26 & 26 & 5 & 5 & 3 & 9 & $\begin{array}{r}74 \\
(40.0 \%)\end{array}$ \\
\hline $\begin{array}{l}\text { HCV positive (Foreign } \\
\text { screeners) }\end{array}$ & 6 & 7 & 1 & 3 & 1 & 1 & $\begin{array}{r}19 \\
(10.3 \%)\end{array}$ \\
\hline Total & 63 & 70 & 15 & 14 & 10 & 13 & 185 \\
\hline
\end{tabular}

province and reported 3a (57.83\%), 3b (6.2\%), 1a (072\%), mixed genotypes (6.73\%) and untypable (27.95\%). The authors of both the studies described above were unable to establish the status of treatment in their enrolled patients. In another study from Lahore (a populated city in Pakistan), Ahmad et al. [34] reported 3a (55.9\%), 3b (3.2\%), 1a (23.6\%), mixed genotypes (1.2\%) and untypable (2.5\%). A more detailed study from Pakistan showed the prevalence of $3 \mathrm{a}(62 \%), 3 \mathrm{~b}(9 \%), 1 \mathrm{a}(3 \%), 2 \mathrm{a}$ $(2.144 \%)$, mixed $(4.718 \%)$ and untypable $(17.16 \%)$ [34]. The present study shows high prevalence of $2 \mathrm{a}$ of $8.1 \%$ genotype in Swati population as compared to that reported from the rest of the country. Genotypes $2 \mathrm{a}$ is common in Europe, North America and Japan [35] which suggest that this genotype may be introduced due to frequent traveling of the local population to these countries.

The high percentage of untypable HCV genotype seen in the current study is due to the status of patients samples used for HCV genotyping as $82.9 \%$ of our untypable cases were from those HCV patients who had received interferon plus ribavirin standard therapy in the past and either they were non-responders or initially responded to therapy (end of treatment response) but later on were relapsed. It is convincing that this high number of samples with untypable genotypes is due to mutations and emergence of new quasispecies that emerged during therapy due to drugs pressure. HCV mutates very rapidly during its replication cycle that permits for the emergence of drug resistance mutations that is very common. Rapid emergence of new

Table 2 Successfully genotyped and non-genotyped samples based on anti-viral treatment status

\begin{tabular}{llll}
\hline Treatment Status & Number of patients samples & Successfully genotyped (\%) & Found untypable (\%) \\
\hline Previously received interferon plus ribavirin therapy & 121 & $63(52.1)$ & $58(47.9)$ \\
\hline Never received interferon plus ribavirin therapy & 11 & $10(90.9)$ & $1(9.1)$ \\
\hline Unknown about treatment & 53 & $42(79.2)$ & $11(20.8)$ \\
\hline
\end{tabular}


resistance strains/quasi-species occurs in a population of viruses already present, allowing the new/resistant virus to become the leading strain, therefore, in order to correctly genotype these newly emerged strains, clinical laboratories may require to up date their genotyping assays as the previously developed assays may not be able to designate a specific genotype/subtype to these strains.

\section{Conclusion}

We conclude that (i) HCV genotypes $3 \mathrm{a}$ is the most prevalent genotype in district Swat (ii) The current genotyping methods fail to genotype the newly emerged strains (iii) Major mode of $\mathrm{HCV}$ transmission is unknown.

\begin{abstract}
Abbreviations
HCV: hepatitis C virus; M-MLV: Molony-murine leukemia virus; KPK: Khyber Pakhtoonkhaw; ABI: Applied Biosystem Inc.; RT-PCR: reverse transcriptase polymerase chain reaction; CDNA: complimentary DNA.
\end{abstract}

\section{Author details}

${ }^{1}$ Department of Genetics, Hazara University Mansehra, Pakistan. ${ }^{2}$ National Centre of Excellence in Molecular Biology, University of the Punjab, Lahore, Pakistan. ${ }^{3}$ Department of Medicine, Saidu Teaching Hospital, Saidu Sharif, Swat, Pakistan. ${ }^{4}$ Division of Molecular Virology, National Centre of Excellence in Molecular Biology, University of the Punjab, Lahore, Pakistan.

\section{Authors' contributions}

AA \& HA conceived the study, participated in its design and coordination and gave a critical view of manuscript writing. IU collected epidemiological data, performed genotype analysis and analyzed the data statistically. MI helped IU in molecular genotyping assays and gave a critical view of manuscript writing and participated in data analysis. SUG, MA, LA and AA helped IU in data analysis. All the authors read and approved the final manuscript.

\section{Competing interests}

The authors declare that they have no competing interests.

Received: 9 December 2010 Accepted: 14 January 2011 Published: 14 January 2011

\section{References}

1. James MC, The Liver and Biliary Tract, Kumar V, Abbas AK, Fausto N: Pathologic Basis of Disease 7th ED.Edited by: Robbins, Cotran. Elsevier Saunders Philadelphia, Pennsylvania 19106; 2005:894.

2. Rho J, Ryu JS, Hur W, Kim CW, Jang JW, Bae SH, Choi JY, Jang SK, Yoon SK: Hepatitis $C$ virus (HCV) genotyping by annealing reverse transcriptionPCR products with genotype-specific capture probes. J of Microbiol 2008, 46(1):81-87.

3. Bartenschlager R, Frese M, Pietschmann T: Novel insights into hepatitis $C$ virus replication and persistence. Adv Virus Res 2004, 63:71-180.

4. Omran HMoataza, Youssef SSamar, El-Garf TWael, Tabll AAshraf, BaderEldin GNoha, Atef K, Nabil W, El-Awady KMostafa: Phylogenetic and Genotyping of Hepatitis C Virus in Egypt. Aus J of Basic and App Sci 2009, 3(1):1-8

5. Ohno T, Mizokami M, Wu R, Saleh MG, Ohba K, Orito E, Mukaide M, Williams R, Lau JYN: New hepatitis C virus (hcv) genotyping system that allows for identification of HCV genotypes 1a, 1b, 2a, 2b, 3a, 3b, 4, 5a, and 6a. J of Clin Microbiol 1997, 35:201-207.

6. Zein N: Clinical significance of hepatitis C virus genotypes. Clin Microbiol Rev 2000, 13:223-235

7. Agnello V, Chung RT, Kaplan LM: A role for hepatitis C infection in type II cryoglobulinaemia. N Engl J Med 1992, 327:1490-5.
8. Brind AM, Watson JP, Burt AD: Non-Hodgkins lymphoma and hepatitis C virus infection. Leukaemia and Lymphoma 1996, 21:127-30.

9. Okada K, Takishita Y, Shimomura H, Tsuji T, Miyamura T, Kuhara T: Detection of hepatitis $\mathrm{C}$ core protein in the glomeruli of patients with membranous glomerulonephritis. Clin Nephrol 1996, 45(2):71-6.

10. Koop CE: Hepatitis C: An epidemic for any one, worldwide prevalence. DHMC 2008 [http://www.epidemic.org/theFacts/theEpidemic/ worldprevalence.php/].

11. World health Organization (WHO): Hepatitis C - global prevalence. Wkly Epidemiol Rec 2000, 75:18-19.

12. Abdel-Hamid M, El-Daly M, Molnegren V, El-Kafrawy S, Abdel-Latif S, Esmat G, Strickland G, Loffredo C, Albert J, Widell A: Genetic diversity in hepatitis $C$ virus in Egypt and possible association with hepatocellular carcinoma. J Gen Virol 2007, 88:1526-1531.

13. Ali A, Ahmed $\mathrm{H}$, Idrees M: Molecular epidemiology of Hepatitis $\mathrm{C}$ virus genotypes in Khyber Pakhtoonkhaw of Pakistan. Virol J 2010, 203:1-7.

14. Helbling B, Stamenic I, Viani F: Interferon and amantadine in naive chronic hepatitis C: a double-blind Randomized placebo-controlled trial. Hepatology 2002, 35(2):447-454.

15. Hoofnagle JH, Di-Bisceglie AM, Shindo M: Antiviral therapy of hepatitis C present and future. J Hepatol 1993, 17(Suppl 3):130-6.

16. Dusheiko G, Schmilovitz H, Brown D, McOmish F, Yap PL, Simmonds P: Hepatitis $C$ virus genotypes: an investigation of type-specific differences in geographic origin and disease. Hepatology 1996, 19:13-18.

17. McHutchison JG, Gordon SC, Schiff ER, Shiffman ML, Lee WM, Rustgi VK Goodman ZD: Interferon alfa-2b alone or in combination with ribavirin as initial treatment for chronic hepatitis C. Hepatitis Interventional Therapy Group. N Engl J Med 1998, 339:1485-1492.

18. Poynard T, Marcellin P, Lee SS, Niederau C, Minuk GS, Ideo G, Bain V, Heathcote J, Zeuzem S, Trepo C, Albrecht J: Randomized trial of interferon alpha2b plus ribavirin for 48 weeks or for 24 weeks versus interferon alpha2b plus placebo for 48 weeks for treatment of chronic infection with hepatitis $C$ virus. International Hepatitis Interventional Therapy Group (IHIT). Lancet 1998, 352:1426-1432.

19. Zein NN, Rakela J, Krawitt EL, Reddy KR, Tominaga T, Persing DH: Hepatitis C virus genotypes in the United States: epidemiology, pathogenicity, and response to interferon therapy. Ann Intern Med 1996, 125:634-639

20. McOmish F, Yap PIL, Dow BC, Follett EAC, Seed C, Keller AJ, Cobain TJ, Krusius T, Kolho E, Naukkarinen R, Lin C, Lai C, Leong S, Medgyesi GA, He'jjas M, Kiyokawa H, Fukada K, Cuypers T, Saeed AA, Al-Rasheed AM Lin $M$, Simmonds P: Geographic distribution of hepatitis $C$ virus genotypes in blood donors: an international collaborative survey. J Clin Microbiol 1994, 32:884-92.

21. Nousbaum JB, Pol S, Nalpas B, Landais P, Berthelot P, Brechot C: The Collaborative Study Group: Hepatitis C virus type 1b (II) infection in France and Italy. Ann Intern Med 1995, 122:161-168.

22. Takada NS, Takase S, Takada A, Date T: Differences in the hepatitis C virus genotypes in different countries. J Hepatol 1993, 17:277-283.

23. Simmonds P, Holmes EC, Cha TA, Chan SW, McOmish F, Irvine B, Beall E, Yap PL, Kolberg J, Urdea MS: Classification of hepatitis C virus into six major genotypes and a series of subtypes by phylogenetic analysis of the NS-5 region. J Gen Virol 1993, 74:2391-9.

24. Cha TA, Kolberg J, Irvine B, Stempien M, Beall E, Yano M, Choo QL, Houghton M, Kuo G, Han JH, Urdea MS: Use of a signature nucleotide sequence of hepatitis $C$ virus for detection of viral RNA in human serum and plasma. J Clin Microbiol 1992, 29:2528-2534.

25. Tokita H, Shrestha SM, Okamoto H, Sakamoto M, Horikita M, lizuka H, Shrestha S, Miyakawa Y, Mayumi M: Hepatitis C virus variants from Nepal with novel genotypes and their classification into the third major group. $J$ Gen Virol 1994, 75:931-936.

26. Tokita $H$, Okamoto $H$, lizuka $H$, Kishimoto $H$, Tsuda F, Lesmana LA, Miyakawa Y, Mayumi M: Hepatitis C virus variants from Jakarta, Indonesia classifiable into novel genotypes in the second (2e and 2f), tenth (10a) and eleventh (11a) genetic groups. J Gen Virol 1996, 77:293-301.

27. deLamballerie $X$, Charrel RN, Attoui H, De Micco P: Classification of hepatitis $C$ virus variants in six major types based on analysis of the envelope 1 and nonstructural 5B genome regions and complete polyprotein sequences. J Gen Virol 1997, 78:45-51.

28. Tokita H, Okamoto H, lizuka H, Kishimoto J, Tsuda F, Miyakawa Y, Mayumi $\mathrm{M}$ : The entire nucleotide sequences of three hepatitis $C$ virus 
isolates in genetic groups 7-9 and comparison withthose in the other eight genetic groups. J Gen Virol 1998, 79:1847-1857.

29. Abdulkarim AS, Zein NN, Germer JJ, Kolbert CP, Kabbani L, Krajnik KL, Hola A, Agha MN, Tourogman M, Persing DH: Hepatitis C virus genotypes and hepatitis $G$ virus in hemodialysis patients from Syria: identification of two novel hepatitis C virus subtypes. Am J Trop Med Hyg 1998, 59:571-576.

30. Idrees M: Common genotypes of hepatitis $C$ virus present in Pakistan. Pak J Med Res 2001, 40(2):46-49.

31. Idrees M: Detection of Six Serotypes of HCV in anti-HCV Positive Patients and rate of ALT/AST abnormalities. Pak J Microbiol 2001, 2:61-65.

32. Directorate of Information Technology, Government of Khyber Pakhtunkhwa. [http://www.khyberpakhtunkhwa.gov.pk/aboutus/AreaPopulation.php], Area and populations.

33. Ahmad A, Ahmad B, Ali A, Ahmad Y: Seroprevalence of HBsAg and anti$\mathrm{HCV}$ in general healthy population of Swat district with frequency of different HCV Genotypes. Pak J Med Sci 2009, 25(5):744-748.

34. Butt S, Idrees M, Akbar H, Rehman I, Awan Z, Afzal S, Hussain A, Shahid M, Manzoor S, Rafique S: The changing epidemiology pattern and frequency distribution of hepatitis C virus in Pakistan. Infect Genet Evol 2010.

35. Grima P, Cataldini S, Tommasi D, Guido M, Gabutti G: Epidemiology of HCV Genotypes in the Area of Lecce. J of Prev Med and Hygi 2000, 41:46-53.

doi:10.1186/1743-422X-8-16

Cite this article as: Inamullah et al:: Hepatitis C virus genotypes circulating in district Swat of Khyber Pakhtoonkhaw, Pakistan. Virology Journal 2011 8:16.

\section{Submit your next manuscript to BioMed Central} and take full advantage of:

- Convenient online submission

- Thorough peer review

- No space constraints or color figure charges

- Immediate publication on acceptance

- Inclusion in PubMed, CAS, Scopus and Google Scholar

- Research which is freely available for redistribution

Submit your manuscript at www.biomedcentral.com/submit
Biomed Central 